\title{
EVALUATING THE POSSIBLE USE OF PHYTOPLANKTON AND ZOOBENTHOS FOR WATER QUALITY ASSESSMENT: A CASE STUDY AT BUNG BINH THIEN RESERVOIR, AN GIANG PROVINCE, VIET NAM
}

\author{
Nguyen Thanh Giao ${ }^{1}$
}

\begin{abstract}
The study aimed to evaluate water quality at Bung Binh Thien Reservoir, in An Giang Province, Viet Nam using Shannon-Wiener species diversity index $\left(H^{\prime}\right)$ and associated average score per taxon (ASPT) calculated from composition of phytoplankton and zoobenthos. The water quality index (WQI) was used as the reference for the quality of surface water. The samples of surface water quality, phytoplankton, and zoobenthos were simultaneously collected at 11 sites during the dry season. The results showed that WQI (57-88) classified water quality from good to medium, $H^{\prime}$ calculated using phytoplankton species (1.12-2.71) presented water quality from medium to bad where as, H'z calculated (0 to 2.07) and ASPT (2-4.21) calculated from zoobenthos species divided water quality from bad to very bad. The findings revealed that assessing water quality should not totally rely on diversity indices ( $\left.H^{\prime}, A S P T\right)$, but compositions of phytoplankton and zooplankton should also be taken into consideration.
\end{abstract}

Keywords: An Giang Province, biodiversity index, phytoplankton, water quality, zoobenthos.

\section{INTRODUCTION}

Water is essential for life and monitoring changes in water quality due to the impacts of socio-economic activities such as domestic, agriculture, industry and services is an important task. The results of water monitoring

\footnotetext{
${ }^{1}$ Department of Environmental Management, College of Environment and Natural Resources, Can Tho University

Email: ntgiao@ctu.edu.vn

Received date: $31^{\text {st }}$ December 2019; Revised date: $9^{\text {th }}$ February 2020; Accepted date: $16^{\text {th }}$ March 2020
}

can be used effectively to manage and improve water quality. Thus, water monitoring is now upheld by standards with environmental laws and policies in most countries. There are several types of water quality monitoring such as continuous monitoring, background monitoring, flux monitoring, or impact monitoring. Choosing the right monitoring indicators make environmental monitoring more accurate and allows for environmental management to be put in place effectively.

In Viet Nam, the central and local environmental management authorities have been monitoring the surface water quality mainly using physicochemical variables. However, observation of the environmental quality of water using phytoplankton and zoobenthos have been recently recommended since it would help to quickly diagnose environmental properties with simple, inexpensive methods with less pollutants generated compared to chemical methods. Certain environmental management authorities in the Vietnamese Mekong delta have been using phytoplankton and zoobenthos for water monitoring [1]. However, limited studies have been conducted using physicochemical, phytoplankton and zoobenthos to evaluate how these methods could work for water quality monitoring simultaneously together. This study was carried out in Bung Binh Thien reservoir in An Phu district, An Giang Province, Viet Nam, to assess the water quality using physicochemical, phytoplankton and zoobenthos testing methods. The findings of the current study could provide important information for the selection of environmental indicators for improved water monitoring. 


\section{BACKGROUND}

For monitoring surface water quality, physicochemical parameters of the water and biological organisms associated with water environment such as phytoplankton, zooplankton and zoobenthos can also be used [2]-[10]. Physicochemical variables including temperature $\left({ }^{\circ} \mathrm{C}\right), \mathrm{pH}$, total suspended solids (TSS, mg/L), turbidity (NTU), dissolved oxygen (DO, mg/L), biological oxygen demand (BOD, mg/L), chemical oxygen demand (COD, mg/L), ammonia $\left(\mathrm{NH}_{4}^{+}\right.$$\mathrm{N}, \mathrm{mg} / \mathrm{L})$, orthophosphate $\left(\mathrm{PO}_{4}^{3-}-\mathrm{P}, \mathrm{mg} / \mathrm{L}\right)$, heavy metals and other metals ( $\mathrm{Fe}, \mathrm{Al}, \mathrm{Mn}$, $\mathrm{Cr}, \mathrm{Cd})$, chloride $\left(\mathrm{Cl}^{-}\right)$, sulfate $\left(\mathrm{SO}_{4}^{2-}\right)$, pesticides, antibiotics, or microorganisms and bacteria such as E. coli and Coliforms (MPN/100mL) have been often used for water monitoring [11]-[13]. The selection of a set of physicochemical indicators for water monitoring depends on the characteristics of the pollution source [4]. In addition to physicochemical parameters, phytoplankton is also selected as an indicator for the quality of water since its diversity and abundance are closely related to the characteristics of water environment such as light, temperature, nutrients, carbon dioxide, bicarbonate, presence of phytoplankton consumers (zooplankton, fish) [4], [14]-[16]. Some phytoplankton phyla such as Bacillariophyta, Cyanophyta and Chlorophyta can be used to indicate nutrient-rich and highly organic water environments [5], [15], [17], [18]. Cyanophyta can be an indicator for static water and an organic-rich water environment. Dinophyta or Pyrrophyta are used to indicate brackish and saltwater environments [18]. Similarly, zoobenthos for example, Oligochaeta, Polychaeta, Insecta, Gastropoda, Bivalvia and Malacostraca, can be used as water quality and sediment property indication since they have a relatively long-life cycle with the affected water source and the bottom of the water body [2], [6]-[8], [10], [19]. Water quality affected by domestic wastewater, urban wastewater, aquaculture wastewater, and landfill operation has previously been inves- tigated using zoobenthos detection methods [6], [10], [14], [15].

\section{MATERIALS AND METHODS}

\section{A. Site description}

Bung Binh Thien is the largest freshwater reservoir in the south of Viet Nam belonging to three communes comprised of Nhon Hoi, Quoc Thai and Khanh Binh of An Phu district in An Giang Province. The water surface area of the reservoir during the dry and wet seasons are 200 and 800 ha, respectively. The average depth of the reservoir is $4 \mathrm{~m}$, the average length is approximately 2,900 $\mathrm{m}$ and the average width is $430 \mathrm{~m}$ [20]. Bung Binh Thien plays a key role in the socio-economic development of this area in An Giang Province. For example, it provides freshwater for domestic use, cultivation and animal husbandry, and aquaculture. However, it is now severely affected by waste from those local activities (domestic, agriculture, and aquaculture) as well as uncontrolled water from upstream from Cambodia. For instance, there is waste such as fast food foam boxes, plastic bottles and pollutants attached to sediment. In the future, Bung Binh Thien reservoir is planned to become a conservation area to maintain biodiversity and to serve as a reserve freshwater for inhabitants in the region for their daily life and other activities. For this reason, Bung Binh Thien reservoir is a good selection for the current research.

\section{B. Water sampling and analysis}

Water quality characterization including physical, chemical and biological parameters was analyzed. The physical variables tested were temperature $\left({ }^{\circ} \mathrm{C}\right), \mathrm{pH}$, total suspended solids (TSS, mg/L), and turbidity (NTU). The chemical variables are dissolved oxygen (DO, mg/L), biological oxygen demand (BOD, mg/L), chemical oxygen demand (COD, $\mathrm{mg} / \mathrm{L})$, ammonia $\left(\mathrm{NH}_{4}^{+}\right.$$\mathrm{N}, \mathrm{mg} / \mathrm{L})$, orthophosphate $\left(\mathrm{PO}_{4}^{3-}-\mathrm{P}, \mathrm{mg} / \mathrm{L}\right)$ and coliforms (MPN/100mL). The 10 water samples (S1-S10) were collected inside the reservoir and one sample (S11) was collected 
in the river (Binh Di river) directly connected to the reservoir. The locations of sample collection in Bung Binh Thien Reservoir are shown in Figure 1.

The water samples were collected inside the reservoir at the onset (S10), at the middle (S4- S9) and at the end of the reservoir (S1$\mathrm{S} 3$ ). The water samples were also collected at the positions close to the reservoir banks (S3, S6, S9, S1, S4, and S7) and at the middle of the reservoir (S2, S5, and S8). The samples were collected during the dry season in January 2019. Temperature and DO were measured in the field using handheld meters. The other parameters of water quality analysis and quality control were performed using standard methods [21].

The surface water quality was assessed by WQI following Equation (1) [22]: $W Q I=$ $\frac{W Q I_{p H}}{100}\left[\frac{1}{5} \sum_{a=1}^{5} W Q I_{a} . W Q I_{b} . W Q I_{c}\right]^{1 / 3}$

Where $\mathrm{WQI}_{a}$ is the WQI value of five parameters $\left(\mathrm{DO}, \mathrm{BOD}_{5}, \mathrm{COD}, \mathrm{NH}_{4}^{+}-\mathrm{N}\right.$, and $\left.\mathrm{PO}_{4}^{3-}-\mathrm{P}\right) ; \mathrm{WQI}_{b}$ is the WQI value of TSS; $\mathrm{WQI}_{c}$ is the WQI value of coliforms and $\mathrm{WQI}_{p H}$ is the WQI value of $\mathrm{pH}$ parameters (ranging from 6 to 8.5).

The WQI value ranging from 0 to 100 divides water quality into five levels. Level $1(100>$ WQI $>91)$ is excellent water quality that can be used for purposes of water supply. Level 2 (90>WQI>76), good water quality, is also used for water supply for domestic use but extra suitable treatment measures are required. Level 3 (75>WQI $>51)$, medium water quality, is for irrigation and other similar purposes. Level 4 (50>WQI $>26)$, bad water quality, is the water suitable for transport and equivalent purposes while Level $5(25>\mathrm{WQI}>0)$, very bad water quality, is considered to be heavily polluted water and proper treatment measures are urgently needed.

\section{Phytoplankton sampling and analysis}

Each sample of phytoplankton was collected by filtering $200 \mathrm{~L}$ of water through $25 \mu \mathrm{m}$ mesh sized nets. The concentrated samples were placed in a $110 \mathrm{~mL}$ vial and fixed with formaldehyde 2-4\%. Qualitative analysis was performed using a microscope with 10X-40X magnification and images of phytoplankton were taken to determine morphological and structural characteristics and classification according to Tien and Hanh; Ho; Tuyen; Fernando, and Reynold [23][27]. Quantitative analysis of the samples were performed by counting individual phytoplankton according to the methods of Boyd and Tucker [28]. The density of phytoplankton was calculated by equation (2):

$$
Y=\frac{X * V_{c} * 1000}{N * A * V_{t}}
$$

Where $\mathrm{Y}$ is phytoplankton density (individuals/liter); $\mathrm{X}$ is the number of individual phytoplankton in the counted cells; $\mathrm{Vc}$ is the concentrated sample volume $(\mathrm{mL})$; N is the number of counted cells; $\mathrm{A}$ is area of counted cells $\left(1 \mathrm{~mm}^{2}\right)$ and $\mathrm{Vt}$ is water volume collected $(\mathrm{mL})$.

The diversity of phytoplankton was examined by calculating Shannon-Wiener diversity index $\left(\mathrm{H}^{\prime}\right)$ following Equation (3):

$$
H^{\prime}=-\sum p_{i} \cdot \ln \left(p_{i}\right)
$$

where $\mathrm{p}_{i}=\mathrm{n}_{i} / \mathrm{N} ; \mathrm{n}_{i}$ is the numbers of ith individual; $\mathrm{N}$ is total amount of individuals in the samples. Water quality is divided by the three levels of pollution based on H' values with H' greater than 3 indicates good water quality or water is not polluted, when $\mathrm{H}^{\prime}$ is in the range of 1 to 3 , this shows moderate water pollution. Finally, when $\mathrm{H}^{\prime}$ is lower than 1, this indicates highly polluted water [19].

\section{Zoobenthos sampling and analysis}

Zoobenthos samples were collected by Petersen grab [8], with an open mouth area equal to $0.02 \mathrm{~m}^{2}$. At each sampling point, collecting benthic species samples were repeated five times. The collected samples were sieved to $0.5 \mathrm{~mm}$ size to remove mud and debris. After that, the sieved samples were stored in nylon bags and fixed with $8 \%$ formaldehyde. The collected samples were 


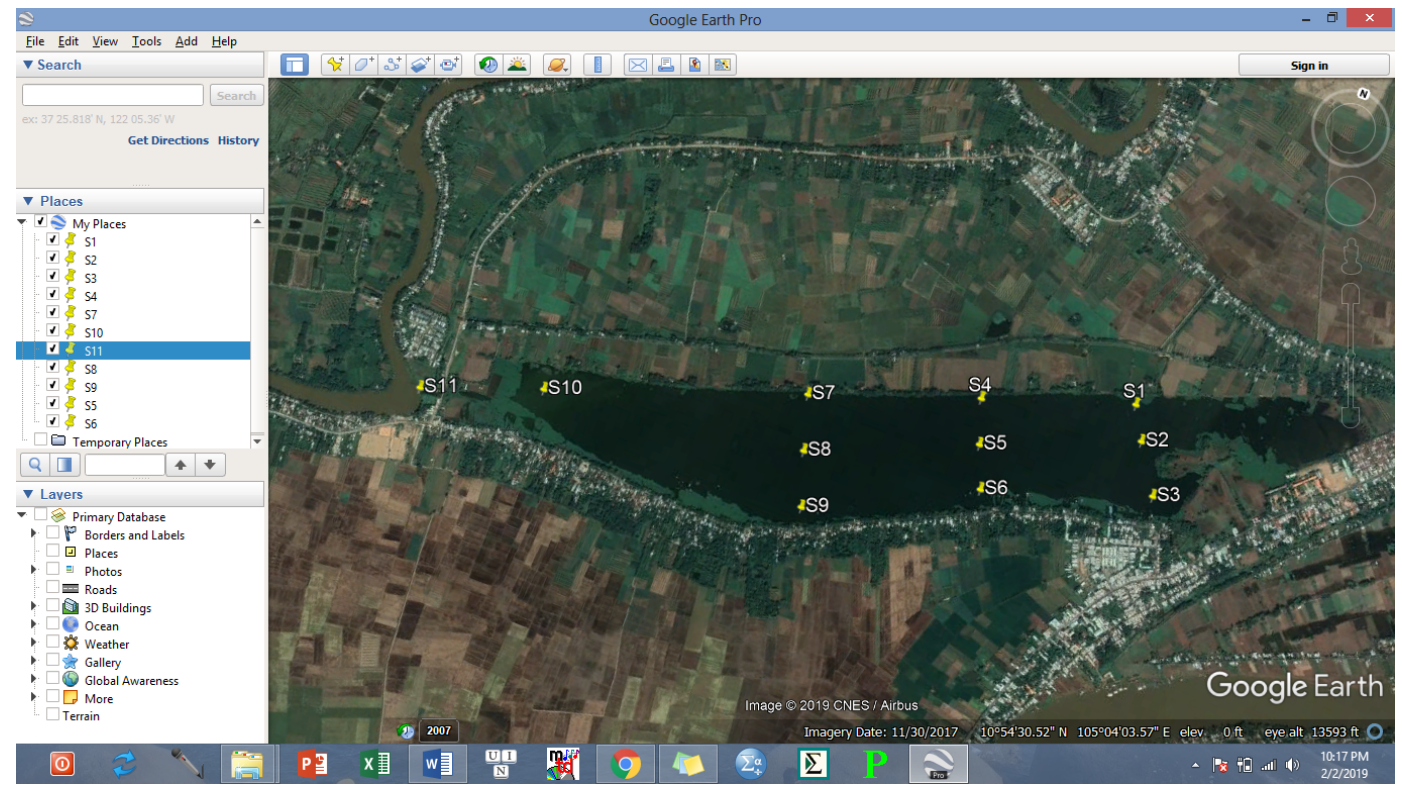

Fig. 1: Locations of sample collection

(Source: Google Earth image, 2019)

transported to the laboratory, at which they were further processed to eliminate any organic matter and to retain only zoobenthos. The collected zoobenthos were fixed with a $4 \%$ formaldehyde solution until qualitative and quantitative analyses were performed. For qualitative analysis, zoobenthos were observed by microscope and with magnifying glasses to determine the structural morphological characteristics and classification characteristics following the taxonomy textbooks of Quynh et al.; Thanh et al.; Hung; Hayward and Ryland; Zamora and Co; and Carpenter and Niem [29]-[34]. For quantitative analysis, the zoobenthos in each sample were counted and the density was determined by Equation (4):

$$
D=X / S
$$

where $\mathrm{D}$ is the density calculated by individual per $\mathrm{m}^{2}, \mathrm{X}$ is the number of counted individuals in the collected sample; $\mathrm{S}$ is the sampling area $(\mathrm{S}=\mathrm{n} \times \mathrm{d}), \mathrm{n}$ is the number of collected Petersen grab, $d$ is the open mouth area of the grab.

Data on species composition and density of zoobenthos was calculated by ShannonWeiner diversity index (H') using Equation 5
[18]:

$$
H^{\prime}=-\sum p_{i} \cdot \ln \left(p_{i}\right)
$$

The associated average score per taxon (ASPT) was calculated based on the scored table of BMWP ${ }^{V I E T N A M}$ (Biological Monitoring Working Party-VIETNAM) [35] using Equation (6) [1]:

$$
A S P T=\frac{\sum_{i=1}^{n} B M W P}{N}(6)
$$

Where $\mathrm{N}$ is total families used for calculating tolerance scale; BMWP is $\mathrm{BMWP}^{V I E T N A M}$.

\section{RESULTS AND DISCUSSION}

A. Physical and chemical characteristics of water at Bung Binh Thien Reservoir

Table 1 presents the 10 physicochemical water quality variables of the 11 sampling points at Bung Binh Thien Reservoir during in the dry season (January 2019). The temperature in the reservoir was in the range of $28.07 \pm 0.06-30.33 \pm 1.36{ }^{\circ} \mathrm{C}$. A former study reported that the temperature of water in the Hau river and field canals in An Giang Province fluctuates in the range of $29-30^{\circ} \mathrm{C}$ 
(average $29.7 \pm 0.7^{\circ} \mathrm{C}$ ) [9] which is in accordance with the current study. The temperature at all sampling points is within a suitable range for aquatic organisms. The $\mathrm{pH}$ of the water was recorded ranging from $7.55 \pm 0.03$ to $7.85 \pm 0.01$, which is slightly basic. The $\mathrm{pH}$ measured in the reservoir was slightly higher than the $\mathrm{pH}$ recorded in the water bodies in An Giang Province (6.9 to 7.1) during 20092016 [9], but still in a favorable ranges for aquatic life, and the national standard recommends $\mathrm{pH}$ should be in the range of 6.08.5. The $\mathrm{pH}$ and temperature do not greatly fluctuate and this is a common property of a tropical region [12], [36]. Turbidity levels were found to be greatest in S10 (11.43 \pm 0.06 NTU) and S11 (9.03 \pm 0.09 NTU) since these two points were in close relation to the river. Prior study also found that turbidity was high, ranging from $12.6 \pm 7.2$ to $131.8 \pm 62.3$ NTU in the river [13]. It was found that DO ranged from $5.33 \pm 0.06$ to $9.17 \pm 0.38$ $\mathrm{mg} / \mathrm{L}$. The significantly higher DO values $(\mathrm{p}<0.05)$ were observed at the points inside the reservoir while the DO values sites close to the river (S10) and in the river (S11) were significantly lower $(\mathrm{p}<0.05)$. The higher values of DO in the reservoir could be due to the diverse and abundant presence of phytoplankton and water hyacinth that release and diffuse oxygen into the water environment. It was found that DO values in the present study were higher compared to those of several other water bodies (4.0 to $5.2 \mathrm{mg} / \mathrm{L}$ ) belonging to An Giang Province over the period of 2009-2016 [9].The higher DO concentration could indicate better selfpurification capacity of the reservoir. BOD was in the range of $9.33 \pm 0.58-11.67 \pm 0.58$ $\mathrm{mg} / \mathrm{L}$, whereas COD was in the range of $14.33 \pm 0.58-17.67 \pm 0.58 \mathrm{mg} / \mathrm{L}$. Both BOD and COD are used as indicators of organic waste concentration in water [37], [38]. They were found higher at the end of the reservoir where there are presence of human activities, such as restaurants and cafeterias. BOD averagely accounts for $65.2 \pm 1.1 \%$ of the COD indicating that almost $35 \%$ of organic matter present in the reservoir are recalcitrant substances. The value of organic matter in the reservoir exceeded the national standard of 2.6 and 1.6 times for BOD and COD [39], respectively, which could potentially pose a high threat to ecological and human health. Fortunately, DO levels are high and this generates a good environmental condition for the decomposition of organic matter. BOD in the reservoir $(9.33 \pm 0.58-11.67 \pm 0.58 \mathrm{mg} / \mathrm{L})$ was substantially higher than that in Hau river and neighboring field canals $(4.1-5.5 \mathrm{mg} / \mathrm{L})$ [9] indicating that the water quality in the reservoir is more organically polluted that the other water bodies in areas of An Giang Province.

Ammonium concentration was not detected (detection limit of $0.03 \mathrm{mg} / \mathrm{L}$ ) in $\mathrm{S} 1$, S3, S4, S5, S7, S8, and S9, although it was detected in S2 $(0.2 \mathrm{mg} / \mathrm{L}), \mathrm{S} 6(0.04 \mathrm{mg} / \mathrm{L})$, S10 (0.10 mg/L) and S11 (0.22 mg/L). Orthophosphate was also not detected (detection limit of $0.03 \mathrm{mg} / \mathrm{L}$ ) at any sampling site except S11 (0.05 mg/L). During 2009-2016, orthophosphate concentration was detected in the river system of An Giang Province, which ranged from 0.03 to $0.47 \mathrm{mg} / \mathrm{L}$ [9], and was higher than that detected in the reservoir during the dry season. Coliform density in the study site ranged from $1900 \pm 346.41$ to $9300 \pm 0.00 \mathrm{MPN} / 100 \mathrm{~mL}$. The coliform density in S4, S8, S10, and S11 exceeded the national regulation surface water quality (allowable limit of $2500 \mathrm{MPN} / 100 \mathrm{~mL}$ ) by 1.72 to 3.72 times [39]. A previous study also found that coliform density in the river networks of An Giang Province exceeded the national regulation by 2.14-7.04 times [9]. This data revealed that the river water was more seriously contaminated with fecal microorganisms than that of the reservoir water. The source of the coliform contamination are from human and animal waste and feces [1], [40]. The overall result indicated that TSS, organic matter, and coliforms has impaired water quality in Bung Binh Thien Reservoir. 
Table 1. Characteristics of surface water at Bung Binh Thien Reservoir

\begin{tabular}{lllllll}
\hline Parameter & S1 & S2 & S3 & S4 & S5 & S6 \\
\hline Temp & $29.2 \pm 0.0$ & $29.0 \pm 0.0$ & $30.3 \pm 0.1$ & $29.5 \pm 0.0$ & $29.23 \pm 0.3$ & $30.1 \pm 0.3$ \\
pH & $7.64 \pm 0.01$ & $7.79 \pm 0.01$ & $7.85 \pm 0.01$ & $7.81 \pm 0.04$ & $7.56 \pm 0.03$ & $7.55 \pm 0.03$ \\
Turbidity & $4.67 \pm 0.06$ & $3.53 \pm 0.06$ & $3.28 \pm 0.04$ & $4.33 \pm 0.08$ & $6.25 \pm 0.06$ & $3.27 \pm 0.09$ \\
TSS & $46.3 \pm 0.6$ & $46.7 \pm 0.6$ & $44.0 \pm 1.0$ & $50.3 \pm 0.5$ & $48.0 \pm 1.0$ & $47.7 \pm 0.6$ \\
DO & $8.8 \pm 0.2$ & $8.9 \pm 0.2$ & $7.7 \pm 0.2$ & $9.0 \pm 0.3$ & $8.1 \pm 0.1$ & $9.2 \pm 0.4$ \\
COD & $17.3 \pm 0.6$ & $17.7 \pm 0.6$ & $17.0 \pm 0.0$ & $17.7 \pm 0.6$ & $15.3 \pm 0.6$ & $15.0 \pm 0.0$ \\
BOD $_{5}$ & $11.3 \pm 0.6$ & $11.7 \pm 0.6$ & $11.0 \pm 0.0$ & $11.7 \pm 0.6$ & $10.0 \pm 0.0$ & $10.0 \pm 0.0$ \\
NH4 $^{+}-\mathbf{N}$ & $0.0 \pm 0.0$ & $0.2 \pm 0.0$ & $0.0 \pm 0.0$ & $0.0 \pm 0.0$ & $0.0 \pm 0.0$ & $0.04 \pm 0.0$ \\
PO $_{4}{ }^{3-}-\mathbf{P}$ & $0 \pm 0$ & $0 \pm 0$ & $0 \pm 0$ & $0 \pm 0$ & $0 \pm 0$ & $0 \pm 0$ \\
Coliforms & $1900 \pm 346$ & $2400 \pm 0$ & $2200 \pm 173$ & $4300 \pm 0$ & $2300 \pm 173$ & $2300 \pm 0$ \\
\hline Parameter & $\mathbf{S 7} 7$ & $\mathbf{S 8}$ & $\mathbf{S 9}$ & $\mathbf{S 1 0}$ & $\mathbf{S 1 1}$ & \\
& & & & & & \\
\hline Temp & $29.4 \pm 0.3$ & $30.3 \pm 1.4$ & $29.6 \pm 0.3$ & $29.3 \pm 0.1$ & $28.1 \pm 0.1$ & \\
pH & $7.71 \pm 0.03$ & $7.74 \pm 0.01$ & $7.56 \pm 0.01$ & $7.7 \pm 0.01$ & $7.75 \pm 0.03$ & \\
Turbidity & $5.33 \pm 0.05$ & $6 \pm 0.05$ & $4.9 \pm 0.06$ & $11.43 \pm 0.06$ & $9.03 \pm 0.09$ & \\
TSS & $47.0 \pm 0.0$ & $48.3 \pm 0.6$ & $49.7 \pm 0.6$ & $53.0 \pm 1.0$ & $53.3 \pm 0.6$ & \\
DO & $8.0 \pm 0.1$ & $7.6 \pm 0.1$ & $8.0 \pm 0.1$ & $6.1 \pm 0.1$ & $5.3 \pm 0.1$ & \\
COD & $16.0 \pm 0.0$ & $14.3 \pm 0.6$ & $15.3 \pm 0.6$ & $17.3 \pm 0.6$ & $15.3 \pm 0.6$ & \\
BOD & $10.0 \pm 0.0$ & $9.3 \pm 0.6$ & $10.0 \pm 0.0$ & $11.3 \pm 0.6$ & $10.0 \pm 0.0$ & \\
NH ${ }^{+}$-N & $0.0 \pm 0.0$ & $0.0 \pm 0.0$ & $0.0 \pm 0.0$ & $0.1 \pm 0.0$ & $0.22 \pm 0.0$ & \\
PO ${ }^{3--P}$ & $0.0 \pm 0.0$ & $0.0 \pm 0.0$ & $0.0 \pm 0.0$ & $0.0 \pm 0.0$ & $0.05 \pm 0.0$ & \\
Coliforms & $2200 \pm 173$ & $4600 \pm 0$ & $2300 \pm 0$ & $9300 \pm 0$ & $9300 \pm 0$ & \\
& & & & & & \\
\hline
\end{tabular}

B. Water quality assessment using water quality index

The water quality index (WQI) for sampling sites at Bung Binh Thien is presented in Figure 2. The WQI values classifies water quality into two types: good (S1-S9) and medium (S10-S11). According to the National Environmental Protection Agency [22] WQI $(90>\mathrm{WQI}>76)$ means good water quality and the water could be used for domestic supply but proper treatment is required, whereas medium water quality (75>WQI $>51$ ) could be used only for agriculture and other equivalent uses. As previously discussed, the water quality in the studied area ranged from medium to good due to the presence of relatively high concentrations of TSS, organic matter, and coliforms. The medium water quality was found in one site in the river (S11) and one site receiving water from that river (S10), since the water was flowing from S11 to S10 during the sampling time. This result was in accordance with previous studies that reveal that the water quality in the rivers that make up the Mekong Delta has been polluted for a long period of time [1], [41].

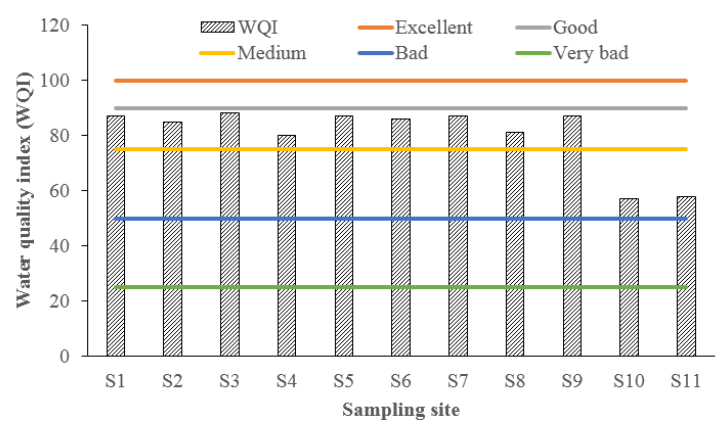

Fig. 2: Water quality indexes at different sampling sites

C. Water quality assessment using phytoplankton

A total of 912 species of phytoplankton belonging to five phyla including Eugleno- 
phyta, Cyanophyta, Bacillariophyta, Chlorophyta and Dinophyta were found at the study site. The number of species at the sampling locations ranged from 36 to 114, where the lowest specie number was found at site $\mathrm{S} 11$. Total density of phytoplankton ranged from 13,082 to 121,452 individuals/L, and the lowest density was found at the site S11. Total density of each phylum was from 12,340 to 285,143 individuals/L (Figure 3a). The percentage of Cyanophyta, Baccillariophyta, Chlorophyta, Dinophyta, and Euglenophyta were $44.0 \%, 34.1 \%, 16.7 \%, 3.6 \%$, and $1.6 \%$, respectively (Figure $3 \mathrm{~b}$ ). The phytoplankton of Cyanophyta, Baccillariophyta, and Chlorophyta were also found to dominate in the constructed wetland areas [4] and rivers [15], [16]. The total number of Chlorophyta, Dinophyta and Euglenophyta were relatively stable from sites $\mathrm{S} 1$ to $\mathrm{S}$ 9, whereas the number of Cyanophyta and Bacillariophyta were highly oscillated. This fluctuation was due to the change in composition of the phytoplankton at each site probably relating to environmental properties such as turbulence, depth, and nutrient content. Phytoplankton at site S11 was less abundant than the other sites. Phytoplankton at the site S10 was also less abundant than that of S1-S9, since S10 was more influenced by the direct connection to the river water at the sampling time. The data of phytoplankton diversity and its abundance corresponding with high turbidity and dissolved oxygen in water was discussed in the previous section.

The presence of Bacillariophyta in the study area indicates that the water environment is nutrient-rich [18], and that these phyla of phytoplankton are very important for aquaculture [5]. Chlorophyta is a favorite food for other aquatic organisms especially fish and shrimp [17]. Cyanophyta is also widely distributed in nutrient-rich water environments [18], and it can utilize dissolved nitrogen from the air since it has the nitrogenase enzyme. Although, its fast growth could lead to eutrophication and cause harm for other aquatic species, and has been seen to not be good for aquaculture [23]. Eugleno- phyta is widely distributed in static, high organic matter and nutrient-rich water bodies, however, it is not suitable as a food source for other aquatic organisms since its cell wall are hard and contains a high level of mucus substances [17]. Dinophyta or Pyrrophyta often occur in brackish or saline water [18]. They could release toxins which cause harm to aquatic species, however, Dinophyta and Bacillariophyta could be the main food source for zooplankton and shrimp larvae [18]. The occurrence of phytoplankton at the sampling sites could indicate several properties relating to the water bodies being tested, for instance, it indicates that there is a nutrient-organic-rich water environment which is taking part in the food chain and food web, as well as facilitating nutrient cycles in the water bodies. The compositional data of phytoplankton was in accordance with turbidity, suspended solids, organic matter, and dissolved oxygen.

The calculated Shannon-Wiener diversity index $\left(\mathrm{H}^{\prime}\right)$ is presented in Figure 4. The values of $H^{\prime}$ ranged from 1.12 to 2.71 corresponding to the quality of the water from medium to bad. The medium water quality was found at the sample sites S1, S2, S4, S5, S6, S8 and S9. Bad water quality means the water should only be used for water transportation and equivalent purposes, which was found at sites S3, S7, S10 and S11. The finding indicates that there is an inconsistency between the use of H' and WQI in reflection of the water quality at these sites, since H' showed worse water quality (good to bad) compared to WQI (good to medium).

\section{Water quality assessment using zooben- thos}

A total of 6 classes and 17 families of zoobenthos were detected at the studied area. The six classes included Oligochaeta (1 family, 3 species), Polychaeta (1 family, 1 species), Insecta (5 families, 7 species), Gastropoda (2 families, 2 species), Bivalvia (4 families, 9 species), and Malacostraca (4 families, 4 species) were identified, of 

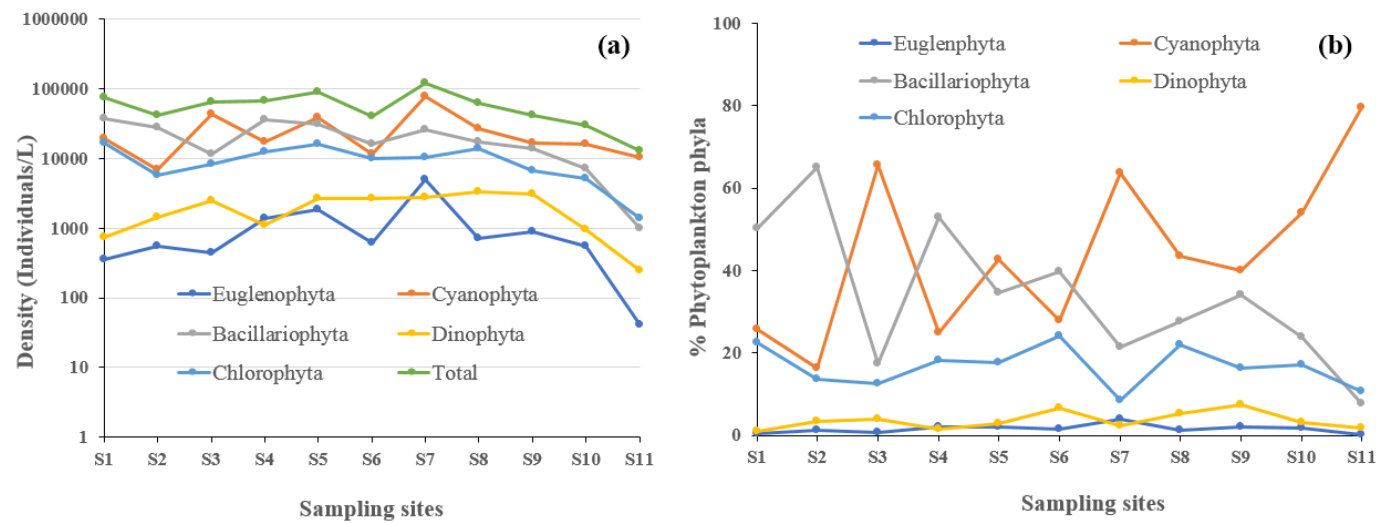

Fig. 3: Density and composition of phytoplankton at Bung Binh Thien Reservoir

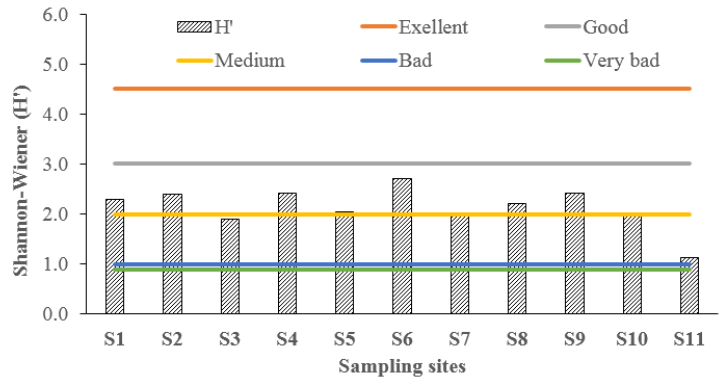

Fig. 4: Water quality using Shannon-Weiner diversity index $\left(\mathrm{H}^{\prime}\right)$

which Polychaeta, Gastropoda, Bivalvia and Malacostraca did not or very rarely present at sites S1-S9, but appeared at sites S10S11 (except Polychaeta). The Insecta and Oligochaeta were in frequent occurrence and dominant classes (Figure 5a). The species of Chaoborus astictopus, Metriocnemus Knabi coq belonging to the families Culicidae and Chironomidae, respectively, were the most frequent occurrence of the class of Insecta. For the Oligochaeta class, Branchyura sowerbyi, Limnodrilus hoffmeisteri, Tubifex $s p$ (Tubificidae family) were the dominant species. These species of the Tubificidae were commonly found in the canals that are being impacted by landfill and by agriculture [10], and indicates the presence of heavy organic pollution sediment [3], [6], [10]. The number of species at the study sites ranged from 1 to 19 species in which the lowest was at site S6 and the highest was at site S11. The lack of diversity in the species of the zoobenthos in the sites from S1 to S9 (1-5 species belonging to 1-2 classes) compared to S10-S11 (10-19 species belonging to 56 classes) could indicate a significant difference in the properties of the sediments. It was observed at the field that the sediment at site S10 and site S11 was hard, light in color and contained sandy materials, whereas the sediment at site $\mathrm{S} 1$ to site $\mathrm{S} 9$ was soft and muddy, dark in color, and contained organic matter. In the previous discussion, the WQI values indicated that the water quality of the samples collected at sites S10 and S11 was much more polluted than that at S1-S9, however, the number of species of zoobenthos at S10 and S11 were considerably higher than those at S1-S9. This could be because zoobenthos could be an indicator for a sediment environment as previously reported by [7], [10]. Future research should also collect sediment sample for analysis of its properties which could be used to elaborate on the role of zoobenthos in indicating environmental properties.

The density of zoobenthos ranged from 640 to 6,600 individuals $/ \mathrm{m}^{2}$. The highest density was found at site S3. This could be due to the effect of waste discharging from the floating restaurant at the site. The density fluctuation was mainly caused by the large change of individuals of Oligochaeta and Polychaeta at each sampling point (Fig- 

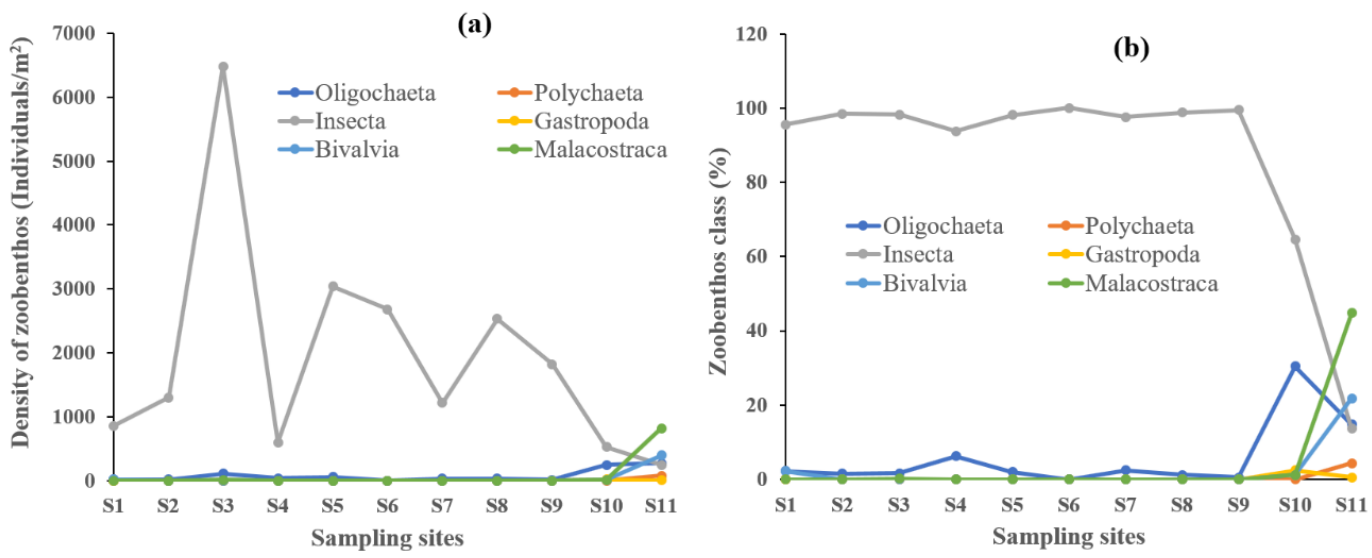

Fig. 5: Density and composition of zoobenthos

ure 5b). The densities of Oligochaeta and Polychaeta at the studied sites ranged from 10 to 270 and from 600 to 6,480 individuals $/ \mathrm{m}^{2}$, respectively (Figure 5a). Using the ShannonWeiner diversity index ( $\left.H^{\prime}\right)$ it was calculated that the zoobenthos diversity at the Bung Binh Thien Reservoir fluctuated from 0 to 2.07 (Figure 6a).The values of $\mathrm{H}^{\prime}$ inside Bung Binh Thien Reservoir (from S1 to S9) were lower than 1, this could indicate that the water quality was very bad or heavily polluted [42]. The water could only be used after appropriate treatment methods are applied. However, the values of H' at S10 (1.88) and $\mathrm{S} 11$ (2.07) revealed that water quality at those sites were better than S1-S9. It could also mean that the zoobenthos at site S10 and S11 were more diverse than those at sites S1-S9. This was consistent with the data of the composition of zoobenthos, where five to six families of zoobenthos were discovered at $\mathrm{S} 10$ and S11, whereas only two or three families of zoobenthos were found at S1-S9. This could be due to the difference in the characteristics of the bottom sediments of the study sites. Further study could adjust the collection method by collecting the sediment samples simultaneously for better data interpretation.

The calculated values of ASPT based on the $\mathrm{BMWP}^{V I E T}$ for the 11 sampling locations were illustrated in Figure $6 \mathrm{~b}$. The ASPT values divided water quality into two levels, one was bad quality or water quality for transportation (S10 and S11), with the other level being very bad quality or heavily polluted (S1-S9).

The use of biological indicators including using phytoplankton and zoobenthos for water quality assessment showed some inconsistency. In this study, the water quality index was used as the standard quality for comparison andusing $\mathrm{H}^{\prime}$ calculated from diversity of phytoplankton (H'p) and H' calculated from zoobenthos (H'z), and ASPT calculated from zoobenthos present. The comparing among WQI, H'p, H'z and ASPT is presented in Table 2. The use of H'p for water quality prediction could lower water quality to level one or two, for example, from good water quality to medium or bad water quality. This could be due to the fact that phytoplankton diversity and composition depends on several factors such as nutrients, organic matter, light, bicarbonate and phytoplankton consumers, such as fish and zooplankton. Using the H'z and ASPT values this indicates very bad to bad water quality whereas WQI shows water quality from good to medium. A previous study also indicated that the use WQI for the assessment of the water quality could result in lower pollution levels than the use of H'z and ASPT calculated from zoobenthos [10] since zoobenthos could be affected by both the properties of sediments and the water column [7]. However, using 

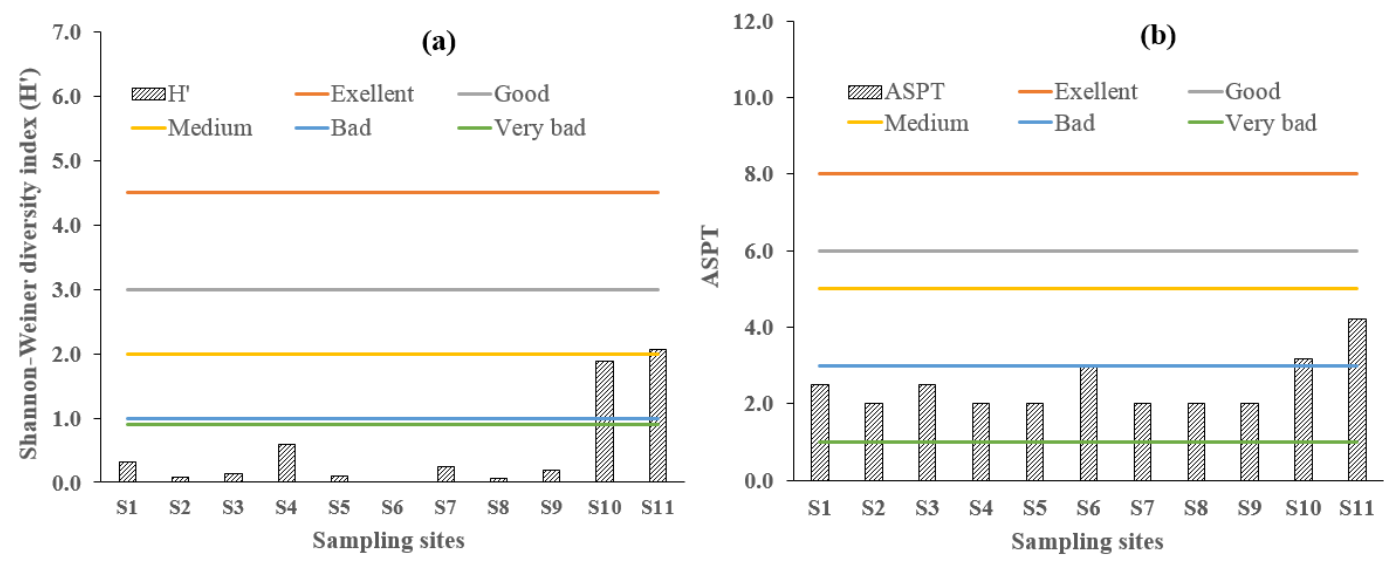

Fig. 6: Water quality assessment using $\mathrm{H}^{\prime}$ and ASPT

$\mathrm{H}^{\prime}$ (for both $\mathrm{p}$ and $\mathrm{z}$ ) and ASPT calculated from zoobenthos lead to the same water quality evaluation, which was also previously reported by Giao [10]. Therefore, the use of H'z (for both $\mathrm{p}$ and $\mathrm{z}$ ) and ASPT should be carefully considered, for example, the values of H'z (for both $\mathrm{p}$ and $\mathrm{z}$ ) of phytoplankton and zoobenthos were calculated based on the diversity of the species, but not species abundance; The obtained ASPT values were based on scoring the family of zoobenthos, and sometimes predicting the water quality may not be accurate since various species in the same family may have different capability of pollution tolerance [43]. The results of the present study suggest that the ShannonWiener diversity index H'z and ASPT should not be solely used to evaluate water quality. Instead, it should be used in combination with physicochemical water parameters. H'z and ASPT should be used for bottom sediment quality assessment and not for water quality assessment.

\section{CONCLUSION}

Water quality at Bung Binh Thien Reservoir during the dry season in January 2019 was polluted by suspended solids, organic matter, and coliforms. The WQI (57-88) values classified water quality from good to medium, and 912 species belonging to five phyla of phytoplankton comprising of Euglenophyta, Cyanophyta, Bacillariophyta,
Chlorophyta and Dinophyta, of which Bacillariophyta, Cyanophyta, and Chlorophyta were dominant. The density of phytoplankton was found to be from 13,082 to 121,452 individuals/L. The Shannon-Weiner diversity index $\left(\mathrm{H}^{\prime}\right)$ of detected phytoplankton (1.12 to 2.71) indicated that the quality of water ranged from medium to bad. For zoobenthos found, six classes including Oligochaeta, Polychaeta, Insecta, Gastropoda, Bivalvia, and Malacostraca were identified in which the Insecta and Oligochaeta most frequently occurred. The density of zoobenthos was in the range of $640-6,600$ individuals $/ \mathrm{m}^{2}$. The values of ' $\mathrm{H}^{\prime}$ of the zoobenthos present in the samples ranged from 0 to 2.07 while ASPT values from 2 to 4.21. Both H'and ASPT values described water quality as bad to very bad quality. There was inconsistency among the water quality indices, therefore utilizing the results of the present study it is recommended that future assessment of water quality should not totally rely on biodiversity indices (H', ASPT) but also include the analysis of the composition of phytoplankton and zooplankton with the participation of the experts in the relevant fields.

\section{REFERENCES}

[1] Ministry of Natural Resources and' Environment. Surface Water Quality; 2012. (In Vietnamese).

[2] Richard ST, Thorne J, Williams WP. The response of benthic macroinvertebrates to pollution in developing 
Table 2. Comparing assessment of water quality using phytoplankton and zoobenthos

\begin{tabular}{lclclcccc}
\hline Site & $\begin{array}{c}\text { WQ } \\
\text { I }\end{array}$ & $\begin{array}{l}\text { Water } \\
\text { Quality }\end{array}$ & $\begin{array}{c}\text { H' }^{\prime} \\
\text { (Phytoplankton) }\end{array}$ & $\begin{array}{l}\text { Water } \\
\text { Quality }\end{array}$ & $\begin{array}{c}\mathbf{H}^{\prime} \\
\text { (Zoobenthos) }\end{array}$ & $\begin{array}{c}\text { Water } \\
\text { Quality }\end{array}$ & $\begin{array}{c}\text { ASP } \\
\text { T }\end{array}$ & $\begin{array}{l}\text { Water } \\
\text { Quality }\end{array}$ \\
\hline S1 & 87 & good & 2.29 & medium & 0.31 & very bad & 2.5 & very bad \\
S2 & 85 & good & 2.39 & medium & 0.09 & very bad & 2.0 & very bad \\
S3 & 88 & good & 1.91 & bad & 0.13 & very bad & 2.5 & very bad \\
S4 & 80 & good & 2.42 & medium & 0.59 & very bad & 2.0 & very bad \\
S5 & 87 & good & 2.04 & medium & 0.10 & very bad & 2.0 & very bad \\
S6 & 86 & good & 2.71 & medium & 0.00 & very bad & 3.0 & very bad \\
S7 & 87 & good & 1.95 & bad & 0.24 & very bad & 2.0 & very bad \\
S8 & 81 & good & 2.20 & medium & 0.06 & very bad & 2.0 & very bad \\
S9 & 87 & good & 2.42 & medium & 0.20 & very bad & 2.0 & very bad \\
S10 & 57 & medium & 1.96 & bad & 1.88 & bad & 3.17 & bad \\
S11 & 58 & medium & 1.12 & bad & 2.07 & medium & 4.21 & bad \\
\hline
\end{tabular}

countries: a multimetric system of bioassessment. Freshwater Biology. 1997;37:671-686.

[3] Plafkin JL, Barbour MT, PorterKD, Gross SK, Hughes RM. Rapid Bioassessment Protocols for Use in Streams and Rivers: Benthic Macroinvertebrates and Fish. EPA/444/4-89-001. U.S. Environ. Prot. Agency, Washington, D.C; 1989.

[4] Cao L, Guisen D, Bingbin H, Qingyi M, Huimin L, Zijian W, et al. Biodiversity and water quality variations in constructed wetland of Yongding River system. Acta EcologicaSinica. 2007;27(9):3670-3677.

[5] Lan LM. Aquatic plants. Can Tho University Publishing House; 2000. (In Vietnamese).

[6] Dung DT, Cong NV, Quyen LC. Using zoobenthos indices for assessment of the polluted water in Tam Bot canal, Long Xuyen, AnGiang province. Can Tho University Journal of Science. 2011;20:18-27. (In Vietnamese).

[7] Lien NTK, Ut VN. Comparing development of zoobenthos at upper, middle and lower parts of Hau River. Journal of Science and Technology. 2016;18:94-102. (In Vietnamese).

[8] Wijeyaratne WMDN Kalaotuwave KMBPP. Evaluation of the water and sediment quality of a lotic waterbody in the western coastal region of Sri Lanka using Rapid Bioassessment Protocol II (RBP II) of benthic macroinverterbrates. Sri Lanka Journal of Aquatic Science. 2017;22(2):85-97.

[9] Ly NHT, Giao NT. Surface water quality in canals in An Giang province, Viet Nam, from 2009 to 2016. Journal of Vietnamese Environment. 2018;10(2):113 119. (In Vietnamese).

[10] Giao NT. The use of zoobenthos for the assessment of water quality in canals influenced by landfilling and agricultural activity. Journal of Vietnamese Environment. 2019;11(1):21-31. (In Vietnamese).

[11] Cho KH, Park Y, Kang J-H, Ki SJ, Cha S, Lee SW, et al. Interpretation of seasonal water quality variation in the Yeongsan Reservoir, Korea using multivariate statistical analyses. Water Science and Technology. 2009;59(11):2219-2226.

[12] Chounlamany V, Tanchuling MA, Inoue T. Spa- tial and temporal variation of water quality of a segment of Marikina river using multivariate statistical methods. Water Science and Technology. 2017;66(6):1510-1522.

[13] Zeinalzadeh K, Rezaei E. Determining spatial and temporal changes of surface water quality using principal component analysis. Journal of Hydrology: Regional Studies. 2017;13:1-10.

[14] Oanh DTH, Lien NTK. Zooplankton, natural food in the rotational rice-tiger shrimp (Penaeus monodon) system. Feed and Feeding Management for healthier Aquaculture and profits. The $7^{\text {th }}$ Regional Aquafeed Forum hold at CanTho University; 2015. (In Vietnamese).

[15] Hoang HTT, Duong TT, Nguyen KT, Le QTP, Luu MTN, Trinh DA, et al. Impact of anthropogenic activities on water quality and plankton communities in the Day River (Red River Delta, Vietnam). Environmental Monitoring and Assessment. 2018;p. 190 67. (In Vietnamese).

[16] Duong TT, Hoang HTT, Nguyen KT, Le QTP, Le ND, Dang DK, et al. Factors structuring phytoplankton community in a large tropical river: Case study in the Red River (Vietnam). Limnologica. 2019;76:82-93. (In Vietnamese).

[17] Bac TC. Fundamental Ecology. Can Tho University Publishing House; 1998. (In Vietnamese).

[18] Oanh DTH, Giang HT, Lien NTK. Fluctuation of phytoplankton community in intensive white leg shrimp (Litopenaeusvannamei) ponds referring to shrimp health status. Can Tho University Journal of Science. 2014;p. 159-168. (In Vietnamese).

[19] Wilhm J, Dorris T. Biological parameters for water quality criteria. Biological Science. 1968;18(6):477481.

[20] Department of Natural Resources and' Environment. Statistics, inventory of land use and land use mapping; 2014. (In Vietnamese).

[21] American Public Health Association. Standard methods for the examination of water and wastewater. 20th ed. Washington DC, USA; 1998.

[22] National Environmental Protection Agency. Guideline 
for calculating water quality index; 2011. Decision No. 879 /QĐ-TCMT.

[23] Tien D D, HanhV. Freshwater algae in Vietnam Classification of green algae. Agricultural Publishing House; 1997. (In Vietnamese).

[24] Ho PH. Algae. Sai Gon Publishing House; 1972. (In Vietnamese).

[25] Tuyen NV. Biodiversity in algae in Vietnam's inland waters. Prospects and challenges. Agriculture Publishing House; 2003. (In Vietnamese).

[26] Fernando CH. A guide to tropical freshwater zooplankton: identification, ecology and impact on fisheries. Backhuys Publishers, Leiden, The Netherlands; 2002.

[27] Reynolds CS. Ecology of Phytoplankton (Ecology, Biodiversity and Conservation). Cambridge University Press, Cambridge; 2006.

[28] Boyd CE, Tucker CS. Water quality and pond soil analyses for aquaculture. Alabama Agricultural Experiment Station, Auburn University, Alabama, USA; 1992.

[29] Quynh NX, Pinder C, Tilling S. Identification of Vietnam freshwater invertebrates. Scientific and Technical Publisher, Hanoi, Vietnam; 2001. (In Vietnamese).

[30] Thanh DN, Bai TT, Mien PV. Identification of North Vietnam freshwater invertebrates. Scientific and Technical Publisher, Hanoi, Vietnam; 1980. (In Vietnamese).

[31] Hung NQ. Atlas of photos: The list of economic aquatic species is mainly in the mangrove ecosystem. Institute of Seafood Research; 2010. (In Vietnamese).

[32] Hayward PJ, Ryland JS. The marine fauna of the British Isles and north-west Europe. vol. 2. Molluscs to chordates, Oxford Clarendon Press; 1990.

[33] Zamora PM, Co L. Guide to Philippine Flora and Fauna, Natural Resources Management Center. Ministry of Natural Resources; 1986.

[34] Carpenter KE, Niem VH. The living marine resources of the Western central Pacifi. vol. 1. Seaweeds, corals, bivalves and gastropods, FAO, Rome; 1998.

[35] Quynh NX, Yen MD, Pinder C, Tilling S. Biological surveillance of freshwaters, using macroinvertebrates, A Practical Manual and Identification Key for Use in Vietnam Field Studies Council. UK; 2000. (In Vietnamese).

[36] Singh KP, Malik A, Sinha S. Water quality assessment and apportionment of pollution sources of Gomti river (India) using multivariate statistical techniques - a case study. Analytica Chimica Acta. 2005;538:355-374.

[37] Galal-Gorchev H, Ozolins G, Bonnefoy X. Revision of the WHO guidelines for drinking water quality. Annalidell'IstitutoSuperiore di Sanità. 1993;29:335345.

[38] Kazi TG, Arain MB, Jamali MK, Jalbani N, Afridi HI, Sarfraz RA, et al. Assessment of water quality of polluted reservoir using multivariate statistical techniques: A case study. Ecotoxicology and Environmental Safety. 2009;72(20):301-309.
[39] Ministry of Natural Resources and' Environment. National technical regulation on surface water quality; 2015. QCVN 08-MT: 2015/BTNMT (In Vietnamese).

[40] Bolstad PV, Swank WT. Cumulative impacts of land use on water quality in a southern Appalachian watershed. J Am Water Resour Assoc. 1997;33(3):519-533.

[41] UNICEF Handbook on Water Quality. United Nations Children's Fund (UNICEF), New York; 2008. QCVN 08-MT: 2015/BTNMT.

[42] People's Committee of An Giang province. Report on the state of environment in five years (2011 -2015) of An Giang province; 2015. (In Vietnamese).

[43] Dung DT, Tam DT, Be NV. Aquatic characteristics in the biodiversity area in the Agro-forestry Area 184, Ca Mau. Can Tho University Journal of Science. 2007;7:85-94. (In Vietnamese). 